\title{
PARTISIPASI POLITIK PEREMPUAN PERSPEKTIF HUKUM ISLAM
}

\author{
Sri W arjiyati \\ U niversitas Islam N egeri Sunan Ampel | Jl. A Yani 117 Surabaya \\ warjiyatisri@gmail.com
}

\begin{abstract}
This article discusses political participation of women from the perspective of Islamic law. In paricular, it will highlights a women political organization called KPPI (Kaukus Politik Perempuan Indonesia or Indonesian political women caucus). There are obstacles and challenges for improving women political participation due to personal, internal and external issues. For personal issues, the political awareness for women is relatively low which needs improvement. For internal perspective, not all available political parties gives space and opportunity for women political development, whereas externally, the improvement of women political participation is so limited that they do not participate in politics and do politics correctly. Islam provides equal opportunity for men and women in politics. This can be seen in many sex-neutral injunctions in the Holy Q ur'an which commands amar ma'ruf nahi munkar (promote the good and prevent the evil). This command encompasses all aspects of life, including politics and state issues. Women are also responsible in this respect. Based on that, Islam provide ground for women to actively in politics. Keywords: women political participation, Islamic Law
\end{abstract}

Abstrak: Artikel ini membahas tentang partisipasi politik perempuan perspektif hukum Islam. Partisipasi politik perempuan di Indonesia tergabung pada Kaukus Politik Perempuan Indonesia (KPPI). Terdapat berbagai hambatan dan tantangan dalam upaya peningkatan partisipasi politik perempuan, baik secara personal, internal maupun eksternal. Secara personal, kesadaran berpolitik bagi perempuan relatif masih rendah, sehingga perlu ditingkatkan. Dari sisi internal, belum semua partai memberikan ruang dan kesempatan bagi pengembangan politik perempuan, sedangkan secara eksternal, peningkatan partisipasi politik perempuan masih mengalami banyak keterbatasan, sehingga perempuan masih relatif rendah untuk masuk dalam politik dan 
berpolitik secara benar. Islam memberikan kesempatan kepada kaum perempuan yang berkecimpung dalam kegiatan politik, ini bisa terlihat pada banyak ayat dalam al-Q ur'an yang memerintahkan amar ma'ruf nahi munkar. Ini berlaku untuk segala macam kegiatan, tidak terkecuali dalam bidang politik dan kenegaraan. Perempuan juga turut bertanggungjawab dalam hal ini. Berdasarkan hal tersebut, maka perempuan dalam Islam juga memiliki hak untuk berpartisipasi dalam politik.

Kata Kunci: partisipasi, politik, perempuan, hukum Islam.

\section{Pendahuluan}

Politik adalah proses pembentukan dan pembagian kekuasaan dalam masyarakat yang antara lain berwujud proses pembuatan keputusan, khususnya dalam negara. Indonesia sebenarnya telah meratifikasi konvensi tentang hak-hak sipil dan politik, yang di dalamnya telah menjamin adanya dua hak demokratik yang mendasar bagi perempuan, yaitu hak memilih (right to vote) dan hak untuk mencalonkan diri dalam pemilihan (right to stand for elections). ${ }^{1}$

Tingkat representasi perempuan yang rendah di lembaga legislatif merupakan pelanggaran hak-hak demokratik fundamental perempuan, yang berarti hak-hak dasar mereka, di antaranya; hak untuk mengungkapkan pendapat, hak dalam pencalonan menjadi anggota lembaga perwakilan, dan hak pencalonan menjadi presiden dan hal-hal lain yang mengandung persekutuan dan penyampaian pendapat yang berkaitan dengan politik. $^{2}$

Pembatasan terhadap hak-hak sipil dan politik yang dialami perempuan di antara penyebabnya adalah karena laki-laki sebagai sebuah kelompok melakukan kontrol terhadap keseluruhan hidup perempuan (termasuk politik pengambilan keputusan tentang

${ }^{1}$ Will Kymlicka, Contemporary Political Philosophy: An Introduction, (O xford: Clarendon Press, 1990), 244.

2 Muhammad Anis Q asim Ja'far, Perempuan dan Kekuasaan: M enelusuri Hak Politik dan Persoalan Gender dalam Islam, (Jakarta: Zaman, 1998),

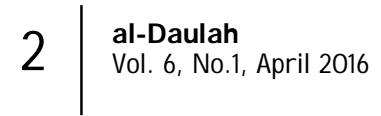


reproduksi, ekonomi dan pekerjaan yang dimiliki perempuan). Laki-laki juga menggunakan kontrol secara individual terhadap nilai ekonomi perempuan dalam perkawinan. ${ }^{3}$

Partisipasi politik perempuan adalah kegiatan sukarela kaum prempuan yang tergabung pada komunitas kaukus perempuan politik. Kaukus ini terdiri dari berbagai unsur, antara lain pemerhati politik, aktivis perempuan, dosen, perempuan parlemen, kader perempuan partai politik dan lain sebagainya, sehingga dalam kaukus ini mereka mengambil bagian pada proses pemilihan penguasa, baik secara langsung atau tidak langsung dalam proses pembentukan kebijakan umum. Menurut Myron Wiener, sifat sukarela dari partisipasi adalah tidak ada pemaksaan, termasuk partisipasi perempuan politik yang dilakukan oleh para komunitas kaukus perempuan politik. Hal ini pada hakekatnya adalah usaha menggali dan memberdayakan potensi-potensi yang dimiliki oleh perempuan.

Secara umum, partisipasi tidak hanya pada bidang politik, akan tetapi dalam segala bidang kehidupan, karena perempuan mempunyai hak dan kewajibannya untuk ikut serta atau berpartisipasi aktif, hanya saja karena selama ini terjadi kesenjangan antara kaum laki-laki dan perempuan yang diakibatkan oleh produk-produk kebijakan yang bias gender, sehingga dibutuhkan perjuangan keras dan keseluruhan dari segenap perempuan dalam segala lini, terlebih pada lini politik yang sangat berpengaruh terhadap produk kebijakan.

Bangsa Indonesia sebagai negara yang merdeka dan berdaulat telah berkomitmen secara tegas memberi pengakuan yang sama bagi setiap warganya, baik itu perempuan maupun laki-laki sama haknya dalam kehidupan berbangsa dan bernegara tanpa kecuali, di mana hak-hak politik perempuan ditetapkan melalui instrumen hukum maupun dengan meratifikasi berbagai konvensi yang menjamin hak-hak politik tersebut. Untuk itu,

${ }^{3}$ W ill Kymlicka, Contemporary Political Philosophy: An Introduction, 244.

\section{3 \begin{tabular}{l|l} 
al-Daulah \\
Vol. 6, No.1 April 2016
\end{tabular}}


partisipasi politik perempuan menekankan bahwa politik dan perempuan sebagai anggota masyarakat mempengaruhi satu sama lain dan bergantung satu sama lain.

Dalam wacana Islam, politik secara sederhana dirumuskan sebagai cara mengatur urusan-urusan kehidupan bersama untuk mencapai kesejahteraan di dunia dan di akhirat. Dengan begitu, politik dalam arti ini sesungguhnya adalah ruang maha luas. Ia muncul dalam ruang domestik dan publik, ruang kultural maupun struktural, personal dam komunal. Penyebutan politik dewasa ini, menyempit menjadi istilah bagi politik praktis, politik struktural, perebutan kekuasaan untuk kepentingan diri atau sebagian orang dan sesaat, bukan lagi untuk kepentingan masyarakat luas dan untuk masa depan yang panjang. Dalam wacana politik Islam klasik, mengangkat pemimpin adalah wajib atas dasar argumen agama dan pikiran rasional. ${ }^{4}$

Dalam Islam, partisipasi perempuan dalam berpolitik tidak dibedakan dengan laki-laki. Namun, terdapat beberapa pendapat ahli hukum Islam tentang partisipasi politik perempuan; pertama, perempuan dilarang menggunakan hak-hak politiknya. Kedua, perempuan diperbolehkan menggunakan hak politiknya dengan alasan pentingnya menyamakan hak laki-laki dan perempuan dalam berpolitik. ${ }^{5}$

Berdasarkan pemikiran dan pertimbangan sebagaimana diuraikan di atas, maka perlu dikaji tentang pentingnya partisipasi politik perempuan perspektif hukum Islam.

\section{Peluang dan Tantangan Politik Perempuan}

Untuk bisa memahami tantangan dan permasalahan perempuan di bidang politik, paling tidak ada empat hal bisa dikaji secara komprehensif. Keempat hal ini merupakan permasalahan yang tidak bisa dipisahkan satu sama lain, saling berkaitan dan saling mempengaruhi. Keempat permasalahan yang

\footnotetext{
${ }^{4}$ Husein Muhammad, Islam Agama Ramah Perempuan, (Yogyakarta: LKiS, 2007), 164.

${ }^{5}$ Ikhwan Fauzi, Perempuan dan Kekuasaan, (Jakarta: Amzah, 2002), 107.
}

\section{4 \begin{tabular}{l|l} 
al-Daulah \\
Vol. 6, No.1 April 2016
\end{tabular}}


sekaligus merupakan tantangan yang harus dipecahkan melalui pendidikan politik bagi kaukus perempuan politik ini adalah sebagai berikut:

1. Dispemahaman gender dan subordinasi perempuan dalam politik

Permasalahan marginalisasi dan ketidakadilan sosial selalu menjadi tema-tema menarik dalam setiap pemikiran dan konsepsi tentang kemasyarakatan di masa sekarang dan yang akan datang. Hal ini seringkali juga mengemuka ketika kaukus perempuan mengadakan pertemuan-pertemuan. Sejarah tentang ketidakdilan ini juga telah memunculkan banyak teori dan analisis sosial yang hingga detik ini masih berpengaruh dalam membentuk sistem sosial di masyarakat, salah satunya masalah ketidakadilan dalam aspek hubungan antar jenis kelamin yang merupakan salah satu dari berbagai macam gugatan yang diajukan para ilmuwan sosial.

Salah satu konsep penting yang perlu dipahami dalam membahas masalah kaum perempuan adalah membedakan antara konsep seks (jenis kelamin) dan konsep gender. Hal ini penting untuk memahami persoalan kaum perempuan, karena ada kaitan yang erat antara perbedaan gender (gender differences) dan ketidakadilan gender (gender inequalities) dengan struktur ketidakadilan masyarakat. Selama kurun waktu ini sering masih terjadi kesalahpahaman dan ketidakjelasan tentang apa yang dimaksud dengan konsep gender dan usaha emansipasi kaum perempuan. Hal ini karena belum ada uraian yang mampu menjelaskan mengenai konsep gender dan mengapa hal ini penting untuk memahami ketidakadilan sosial. Untuk memahami konsep gender perlu dibedakan kata gender dengan seks (jenis kelamin). Pengertian jenis kelamin merupakan pensifatan atau pembagian dua jenis kelamin manusia yang ditentukan secara biologis yang melekat pada jenis kelamin tertentu. Secara permanen ini tidak dapat diubah dan merupakan ketentuan biologis, sering dikatakan sebagai

\section{5 \begin{tabular}{l|l} 
al-Daulah \\
Vol. 6, No.1 April 2016
\end{tabular}}


kodrat, ${ }^{6}$ sedangkan konsep gender yakni suatu sifat yang melekat pada kaum laki-laki maupun perempuan yang dikonstruksikan secara sosial maupun kultural. Misalnya, perempuan dikenal lemah lembut, cantik, emosional, atau keibuan. Sementara laki-laki dianggap kuat, rasional, jantan, perkasa. Ciri dan sifat itu sendiri sebenarnya dapat dipertukarkan. Artinya laki-laki bisa saja lemah lembut, emosional, kebapakan/keibuan sementara ada juga perempuan yang kuat dan perkasa. Perubahan ciri dan sifat itu dapat terjadi dari waktu ke waktu dan dari satu tempat ke tempat lain ${ }^{7}$ Sejarah perbedaan ini dikarenakan oleh banyak hal, di antaranya dibentuk, disosialisasikan, diperkuat bahkan dikonstruksi secara sosial atau kultural, melalui ajaran keagamaan ataupun negara. Dan akhirnya, dianggap sebagai ketentuan Tuhan dan dipahami sebagai kodrat laki-laki dan perempuan. Perbedaan-perbedaan inilah yang pada tingkat selanjutnya, melahirkan ketidakadilan sosial, terutama bagi wanita.

Sebenarnya perbedaan gender tidak akan menjadi masalah apabila tidak melahirkan gender inequality, tapi masalahnya, perbedaan gender ternyata melahirkan persoalan rumit, di mana laki-laki dan perempuan menjadi korban dari sistem dan struktur ketidakadilan tersebut. Ketidakadilan gender ini termanifestasikan dalam berbagai bentuk, yaitu marginalisasi/proses pemiskinan ekonomi, subordinasi atau anggapan perempuan tidak penting dalam keputusan politik, pembentukan stereotipe atau pelabelan negatif, kekerasan (violence), beban kerja lebih panjang dan lebih banyak (burden), serta sosialisasi ideologi nilai peran gender. ${ }^{8}$ Manifestasi ketidakadilan ini tidak bisa dipisah-pisah, saling berkaitan, saling mempengaruhi secara dialektis. Tidak ada satupun

${ }^{6}$ Mansour Fakih, Analisis Gender dan Transformasi Sosial, (Yogyakarta: Pustaka Pelajar, 2001), 8.

$7 \mathrm{lbid}, 8-9$.

$8 \mathrm{lbid}, 12$. 
manifestasi yang lebih penting dan lebih esensial. Misalnya, anggapan bahwa pemiskinan perempuan di wilayah ekonomi adalah lebih penting dan mendasar sehingga harus dipecahkan terlebih dulu. Manifestasi gender yang menimbulkan subordinasi pada perempuan, terutama karena sifat-sifat yang melekat dan dikonstruksikan pada perempuan. Anggapan bahwa perempuan irrasional dan lemah lembut mengakibatkan perempuan tidak bisa dan mampu tampil sebagai pemimpin, sehingga pada akhirnya, jarang sekali perempuan yang bisa tampil di ranah publik dan politik atau menduduki jabatanjabatan strategis dalam partai politik atau lembaga politik formal lainnya.

2. Budaya politik patriarki

Subordinasi perempuan di bidang politik juga diakibatkan karena adanya budaya politik patriarki yang menjadi acuan dalam proses politik. Hal ini seperti pemikiran Muhaimin, ${ }^{9}$ bahwa budaya politik pada hakekatnya berpusat pada imajinasi (pikiran dan perasaan) manusia yang merupakan dasar dari semua tindakan. Tindakan ini dilandasi oleh nilainilai yang telah berkembang dalam diri warga negara, baik sebagai individu maupun kelompok. Nilai-nilai yang disokong oleh tradisi ini membentuk budaya politik.

Masyarakat Indonesia, yang secara sosio kultural merupakan masyarakat plural mempunyai satu bentuk sistem politik yang spesifik karena adanya peran militer yang unik. Rezim militer memperlihatkan gaya laki-laki dan ini terpenetrasi dalam budaya dan etos politik formal. Budaya dan etos politik ini diwarnai oleh gaya hidup maskulin, sehingga akhirnya laki-lakilah yang memformulasi aturan-aturan politik sesuai nilai dan norma laki-laki.

${ }_{9}^{9}$ Muhaimin, M enuju Kemandirian Politik Perempuan (U paya M engakhiri Depolitisasi Perempuan di Indonesia), (Yogyakarta: Kibar Press, 2008), 186. 
Ada dua kekhasan yang melekat pada budaya politik Indonesia: ${ }^{10}$ Pertama, struktur hubungan yang memperlihatkan adanya hubungan patron-klien (bapak-anak atau bawahanatasan). Kedua, adanya rasa kekeluargaan dan persaudaraan. Meskipun dua hal tersebut adalah percampuran berbagai macam budaya, namun budaya dari suku Jawalah yang paling dominan. Dominasi ini karena memang orang Jawa yang senantiasa mendominasi kehidupan politik bangsa ini.

Hubungan patron-klien pada akhirnya akan melahirkan dominasi laki-laki dan mengucilkan perempuan di dunia politik. Dalam hubungan keluarga misalnya, posisi ayah menempati urutan utama dan pertama, sedangkan ibu tidak mempunyai pengaruh dalam pengambilan keputusankeputusan dalam keluarga. Pada akhirnya, ayahlah yang menempati struktur sosial tinggi dalam masyarakat, sementara ibu hanya berada posisi 'melegitimasi' keputusan tersebut.

Berdasarkan fenomena di atas, maka hubungan sosial merupakan basis dan sumber hubungan politik ${ }^{11}$. Dalam hubungan sosial politik kelihatan bahwa masyarakat Jawa bersifat personal. Semua kecenderungan sosio kultural ini memperkental sistem patron-klien, di mana digunakan untuk menjaga harmoni dalam masyarakat. Hal ini diakibatkan oleh sistem pemerintahan jaman dulu yang bersifat sentralistik dimana seorang raja cenderung mewariskan kekuasaannya pada laki-laki, sehingga tidak ada bagian untuk perempuan, karena semuanya telah habis dibagi kepada laki-laki.

3. Hambatan yang bersifat individual

Adanya ketimpangan gender telah membuat pandangan terhadap perempuan berbeda. Sejak awal, perempuan sudah dibesarkan dan dikondisikan untuk merasa tidak aman dan tidak nyaman terhadap dunia politik. Hal ini mengakibatkan perempuan menjadi tidak percaya diri dan tidak tertarik

10 lbid, 187.

11 Ibid, 189. 
dengan politik. Faktor lain adalah rendahnya tingkat pendidikan perempuan, kurangnya akses terhadap informasi dan teknologi, termasuk pemahaman tentang sistem politik kita. Mutu dan kualitas SDM ini hanya bisa ditingkatkan manakala ada political will dari pemerintah.

4. Hambatan yang bersifat kelembagaan dan struktural

Sikap maskulin dari sistem politik kita, di mana peraturanperaturan yang bersifat diskriminatif dan bias gender, tindakan affirmatif tanpa sanksi di UU Pemilu, ini merupakan rintangan bagi perempuan untuk terlibat aktif dalam politik dan kebijakan publik. Sistem pendidikan nasional yang tidak memberikan info cukup untuk pendidikan kesetaraan gender, misalnya terlihat dari banyaknya buku ajar untuk anak-anak sekolah yang masih bias gender. Sistem perencanaan pembangunan "top down' yang bias gender, serta kurangnya pemahaman isu-isu gender dari pejabat pemerintah dan pembuat kebijakan dari pusat hingga daerah. Untuk meningkatkan kualitas demokrasi, diperlukan peningkatan keterwakilan perempuan pada lembaga legislatif, sehingga kebijakan-kebijakan yang dibuat lebih berpihak pada keharmonisan dan berkeadilan gender.

\section{Perkembangan Peran Perempuan dalam Politik}

Perkembangan peran perempuan dalam politik tidak bisa dipisahkan dari bangsa Indonesia setelah meratifikasi konvensi tentang hak-hak sipil dan politik, yang di dalamnya menjamin adanya dua hak demokratik yang mendasar bagi perempuan, yaitu hak memilih (right to vote) dan hak untuk mencalonkan diri dalam pemilihan (right to stand for elections). Salah satu perkembangan peran perempuan dalam politik dapat dilihat dari perkembangan jumlah perempuan yang duduk dalam lembaga legislatif. Adanya tingkat representasi perempuan yang rendah di lembaga legislatif merupakan pelanggaran hak-hak demokratik

\section{9 \begin{tabular}{l|l} 
al-Daulah \\
Vol. 6, No.1 April 2016
\end{tabular}}


fundamental perempuan, karena hal tersebut merupakan hak-hak dasar mereka.

Selanjutnya Ja'far menyatakan bahwa hak-hak politik perempuan adalah partisipasi individu dalam pembentukan pendapat umum. Hak-hak tersebut, terutama dalam bidang politik, meliputi hak untuk mengungkapkan pendapat, hak dalam pencalonan menjadi anggota lembaga perwakilan, dan hak pencalonan menjadi presiden dan hal-hal lain yang mengandung persekutuan dan penyampaian pendapat yang berkaitan dengan politik.12 Namun, terjadi pembatasan terhadap hak-hak politik perempuan, karena laki-laki melakukan kontrol terhadap keseluruhan hidup perempuan (termasuk politik pengambilan keputusan tentang reproduksi, ekonomi dan pekerjaan yang dimiliki perempuan). Laki-laki juga menggunakan kontrol secara individual terhadap nilai ekonomi perempuan dalam perkawinan ${ }^{13}$. Pembatasan seperti ini muncul sebagai akibat dari interpretasi terhadap teks-teks agama yang bias gender.

Selama ini, laki-laki telah menciptakan situasi dan norma serta mendefinisikan peran bahwa perempuan mempunyai tugas membesarkan anak dan tugas domestik lain sebagai tugas perempuan. Hal ini menyebabkan munculnya ketidaksetaraan antara laki-laki dan perempuan, di mana perempuan tidak memiliki posisi di dalam masyarakat dan beberapa posisi penting dalam masyarakat ditempati laki-laki. Perempuan secara ekonomi juga menjadi bergantung kepada laki-laki dan kepada sumber daya yang dimiliki laki-laki, sehingga perempuan tidak memiliki otonomi bagi dirinya sendiri.

Sebagai bagian dari warga negara, perempuan mempunyai hak untuk mendapatkan akses maupun berpartisipasi dalam kekuasaan (politik) dan pengambilan keputusan, termasuk hak untuk memilih dan dipilih, atau memegang posisi penting di

\footnotetext{
12 Muhammad Anis Q asim Ja'far, Perempuan dan Kekuasaan: M enelusuri H ak Politik dan Persoalan Gender dalam Islam, 36.

${ }^{13}$ W ill Kymlicka, Contemporary Political Philosophy: An Introduction, 244.
}

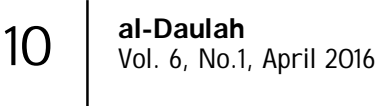


semua tingkatan pemerintahan. Hak ini dijamin dalam UndangUndang Dasar Negara Republik Indonesia Tahun 1945 Pasal 27 dan Pasal 28, Undang-Undang Nomor 39 Tahun 1999 tentang Hak Asasi Manusia dengan bab khusus tentang Hak-hak Perempuan, serta diperkuat oleh Deklarasi PBB mengenai Hak Asasi Manusia, Konvensi PBB tentang Hak-hak Politik Perempuan (diratifikasi dengan Undang-Undang Nomor 68 Tahun 1958 tentang Pengesahan Konvensi tentang Hak-hak Politik Perempuan (The Convention on Political Rights for Women) dan Konvensi PBB tentang Penghapusan Segala Bentuk Diskriminasi terhadap Perempuan / Convention on the Elimination of All Forms of Discrimination against Women/CEDAW (diratifikasi dengan Undang- Undang Nomor 7 Tahun 1984 tentang Pengesahan Konvensi mengenai Penghapusan Segala Bentuk Diskriminasi terhadap Perempuan).

Perempuan perlu mengaktualisasikan dirinya dengan berpartisipasi dalam lembaga-lembaga politik (legislatif) maupun dalam kehidupan publik. Perempuan perlu menempati posisi dalam lembaga politik agar dapat terlibat langsung dalam proses pengambilan keputusan, karena kebijakan dan program yang disusun juga akan berlaku bagi perempuan. Semua kebijakan publik yang dikeluarkan oleh lembaga politik pada akhirnya akan menjangkau semua aspek kehidupan semua warga negara, baik laki-laki maupun perempuan. Selain itu, perempuan yang berjumlah lebih dari setengah jumlah penduduk Indonesia juga mempunyai hak untuk didengar suaranya dan mendapatkan manfaat dari proses pembangunan. Perempuan mempunyai hak yang sama dengan laki-laki, namun partisipasi perempuan dalam kegiatan politik serta kesempatan dan kemampuan untuk berperan serta dalam pengambilan keputusan menunjukkan peningkatan yang sangat lambat. Hal ini dapat dilihat dari jumlah perempuan yang duduk di lembaga legislatif, eksekutif maupun yudikatif.

Di lembaga legislatif secara nasional, keterwakilan perempuan dalam parlemen berada pada peringkat ke-89 dari 189

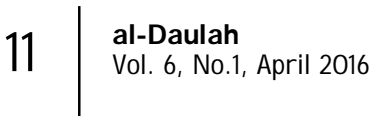


negara. ${ }^{14}$ Hasil Pemilu tahun 2004 menempatkan 65 orang $(11,82 \%)$ perempuan di lembaga DPR, hanya meningkat sedikit apabila dibandingkan dengan pemilu sebelumnya (Pemilu 1999 menghasilkan 44 orang perempuan yang duduk di DPR atau sekitar 8,9\%). ${ }^{15}$ Sementara itu di lembaga Dewan Perwakilan Daerah (DPD) jumlah perempuan agak lebih besar, mencapai 29 orang $(21,09 \%) .{ }^{16}$ Di tingkat daerah, partisipasi politik perempuan juga belum menunjukkan kemajuan yang signifikan, meskipun secara yuridis perempuan memiliki hak politik yang sama dengan laki-laki. Pasal 58 Undang-undang Nomor 32 Tahun 2004 tentang Pemerintahan Daerah memberikan peluang yang sama kepada laki-laki dan perempuan untuk menjadi calon kepala daerah dan wakil kepala daerah. Akan tetapi sampai saat ini, dari 33 provinsi yang ada di Indonesia, baru 1 provinsi yang dipimpin oleh perempuan, yaitu Provinsi Banten. Satu provinsi lainnya, yaitu Jawa Tengah, baru-baru ini memunculkan perempuan sebagai wakil gubernurnya. Sementara itu, di berbagai provinsi lainnya, perempuan baru mampu mencapai posisi tertinggi sebagai bupati atau wakil bupati. Demikian pula dengan keterwakilan perempuan dalam lembaga perwakilan rakyat daerah (DPRD), baik DPRD Provinsi maupun DPRD Kabupaten/Kota. Di Provinsi Jumlah DPRD sebanyak 1.850, dengan jumlah perempuan 188 (10\%) dan laki-laki 1.662 (90\%), sedangkan DPRD di Kabupaten / Kota sebanyak 13.125, dengan jumlah perempuan $1.090(8 \%)$ dan laki-laki 12.046 (92\%).

Berdasarkan data tersebut, hanya dua provinsi yang memiliki angka keterwakilan perempuan dalam DPRD yang cukup tinggi, yaitu Gorontalo dan Sulawesi Utara. Di beberapa provinsi, keterwakilan perempuan dalam DPRD Provinsi, bahkan kurang

\footnotetext{
14 Panduan Rencana Aksi Peningkatan Partisipasi Politik Perempuan, (Jakarta: Deputi Peningkatan Kualitas Hidup Perempuan, Kementerian Negara Pemberdayaan Perempuan Republik Indonesia, 2006), 5.

$15 \mathrm{Ibid}$.

16 MB. Wicaksono (ed), M odul Perempuan untuk Politik: Sebuah Panduan tentang Partisipasi Perempuan dalam Politik, (Jakarta: Yayasan Jurnal Perempuan, 2004), 7.
} 
dari 4\%, seperti Nanggroe Aceh Darussalam, Bali, Nusa Tenggara Barat, Nusa Tenggara Timur, Kalimantan Barat, Kalimantan Tengah, dan Kalimantan Timur. Meskipun tidak berkaitan secara langsung, minimnya jumlah perempuan yang duduk di lembaga legislatif pada gilirannya juga akan mempengaruhi setiap proses pengambilan keputusan yang dilakukan oleh lembaga tersebut berikut hasilnya. Secara tidak langsung, perempuan telah dirugikan dengan kondisi ini. Terlebih lagi, perempuan memiliki kebutuhan-kebutuhan khusus yang berbeda dengan laki-laki, sehingga keterlibatan perempuan dalam lembaga legislatif dengan jumlah yang memadai diharapkan dapat lebih mengakomodasikan kebutuhan perempuan.

\section{Upaya-Upaya Meningkatkan Partisipasi Perempuan dalam Politik}

Agar partisipasi perempuan dalam politik dapat ditingkatkan, perempuan harus melakukan beberapa strategi dan metode untuk mencapai tujuan tersebut, ${ }^{17}$ agar representasi perempuan dalam politik dapat ditingkatkan, sehingga berbagai tradisi yang menghambat perempuan dapat ditembus, maka perempuan harus mempunyai beberapa strategi dan metode pendidikan untuk mencapai tujuan tersebut dengan cara, di antaranya sebagai berikut: ${ }^{18}$

a) Perempuan harus bersama-sama berjaringan, baik di dalam dan di luar partai partai politik. Adanya kegiatan mengorganisir diri, perempuan akan mempunyai posisi tawar yang lebih kuat. Selanjutnya, perempuan dalam organisasi-organisasi ini melakukan penyadaran hak-hak perempuan di lingkungan komunitasnya, seperti pada kaukus perempuan politik dj Jawa Timur.

\footnotetext{
${ }^{17}$ Baca laporan penelitian Herry Triwanto, Profil Perempuan Anggota DPRD Provinsi Jawa Tengah Ditinjau Dari Perspektif Politik Gender, (Tesis-Semarang: PPS U niversitas diponegoro, 2009), 91-94.

18 Ibid., $72-75$.
} 
b) Perempuan melakukan lobi-lobi intensif untuk mendesak partai politik mengeluarkan aturan permainan yang jelas dalam proses seleksi calon, sehingga dapat menyingkirkan semua hambatan-hambatan yang secara langsung maupun tidak langsung mendiskriminasi partisipasi perempuan. Selain itu, perempuan perlu mendesak pada negara atau pemerintah untuk melakukan aksi affirmasi untuk meningkatkan keterwakilan perempuan dalam bidang politik, misalnya melalui pendidikan politik khusus untuk perempuan, penerapan sistem pemilu kuota, mengamandemen undang-undang politik yang bias gender, dan lain sebagainya.

c) Menggunakan media massa secara efektif untuk mengkampanyekan isu-isu, masalah perempuan, dan kebutuhan perempuan dan isu untuk menyeimbangkan partisipasi dan representasi perempuan dan laki-laki. Media massa juga sangat efektif untuk mendidik dan memobilisasi suara, serta dapat dimanfaatkan sebagai sarana pendidikan politik bagi perempuan, karena mereka dapat menjangkau sampai ke pelosok desa.

d) Perlunya menggalang dukungan, komitmen dan kepercayaan kaum laki-laki dan semua pihak bagi para perempuan yang akan mencalonkan diri menjadi anggota partai politik atau anggota legislatif atau eksekutif; serta

e) Perlu adanya metode pelatihan politik bagi kandidat perempuan yang benar-benar dapat meningkatkan pengetahuan dan kemampuannya dalam memimpin, mengatur dan memainkan strategi politik mereka, serta meningkatkan kepercayaan diri perempuan.

\section{Peran Partai Politik dalam Peningkatan Partisipasi Politik Perempuan}

Peran partai politik dalam meningkatkan partisipasi politik perempuan sangat ditentukan oleh partai politik yang 
bersangkutan, sehingga reformasi di level partai politik merupakan langkah strategis dalam meningkatkan partisipasi politik perempuan. Hal ini mengemuka sebagai hasil setiap pertemuan-pertemuan yang dilakukan pada kaukus perempuan politik di Jawa Timur. Kebijakan internal parpol utamanya di tingkat pusat sangat mempengaruhi posisi dan keterwakilan perempuan di parpol sebagai caleg, maupun sebagai anggota legislatif. Mengenai pentingnya reformasi di level partai politik beserta hambatan-hambatannya dapat dipetakan sebagai berikut:

Pertama, partai politik sampai saat ini masih dianggap sangat kurang memiliki komitmen untuk mendorong perempuan masuk dan terpilih dalam lembaga politik formal. Kepengurusan di parpol sendiri masih didominasi laki-laki, kalaupun ada perempuan, banyak yang bukan di posisi yang strategis, sehingga masuknya perempuan dalam kepengurusan Parpol masih belum mampu memberikan warna perubahan yang lebih baik bagi keterlibatan dan peran perempuan dalam proses-proses pengambilan keputusan.

Kedua, minimnya keterwakilan perempuan dalam kepengurusan parpol sangat berpengaruh pada kebijakan yang diambil parpol, khususnya dalam mengimplementasikan UU pemilu yang mensyaratkan kuota $30 \%$ bagi perempuan. Untuk itu perlu ada upaya untuk mendorong adanya ketentuan UU atau kebijakan lain yang juga mengatur implementasi kuota 30\% dalam badan kepengurusan Parpol. Berkaitan dengan hal ini, berdasarkan hasil penelitian yang dilakukan pada tahun 2004, bahwa 90\% pengurus Parpol ternyata tidak sepenuhnya memahami visi misi Parpol, sehingga mengakibatkan proses pendidikan politik dan mekanisme pengkaderan dalam tubuh Parpol memang masih lemah.

Ketiga, kebijakan internal Parpol terhadap caleg perempuan khususnya (dan pembinaan kader atau anggota perempuan partai politik umumnya) dianggap tidak mendukung secara sungguhsungguh dan jujur. Perempuan cenderung didukung hanya untuk 
dijadikan alat oleh parpol untuk memenuhi kuota di tahap awal, sedangkan ditahap selanjutnya dukungan diberikan kepada lakilaki. Hal ini tampak pada pemberian nomer urut besar dan dapil yang bukan daerah binaan atau asal caleg perempuan. Partai cenderung hanya mendukung caleg perempuan yang dianggap potensial, tanpa adanya transparansi dalam pengkategorian tersebut. Masih perlu dielaborasi apakah pengkategorian potensial tidaknya kader untuk dipilih sebagai caleg untuk dipilih sebagai anggota legislatif hanya berlaku bagi perempuan atau juga untuk laki-laki.

Keempat, dari sisi Parpol sendiri muncul adanya keluhan sulitnya mencari kader perempuan yang berkualitas. Hal itu lebih diperparah dengan kenyataan bahwa kaderisasi perempuan di tubuh Parpol masih sangat kurang.

Kelima, sistem Pemilu dapat pula berpengaruh pada peningkatan perempuan untuk duduk di politik., karena dengan zipper system pada Pemilu diharapkan mampu memperbesar peluang perempuan untuk terpilih ternyata masih belum dipatuhi pelaksanaanya oleh parpol, sehingga perempuan banyak ditempatkan di urutan terakhir dari kelipatan 3, misalnya di nomor 3, 6, 9 dan seterusnya. Bahkan banyak kasus ditemukan urutan no 1-3 diisi oleh caleg laki-laki sementara caleg perempuan baru ditempatkan diurutan berikutnya. Lebih parah lagi, banyak caleg perempuan tidak mengetahui dia berada di nomor urutan berapa pada saat parpol menyerahkan daftar calegnya ke KPU. Mereka baru mengetahui nomornya setelah KPU mengumumkan daftar calon tetap (DCT). Hal itu menunjukkan belum adanya transparansi dari Parpol dalam proses penentuan nomor urut calegnya.

Berangkat dari beragam faktor pendukung dan penghambat bagi caleg perempuan untuk duduk di dewan, maka peluang masuknya perempuan ke dalam legislatif dilakukan melalui tiga cara: 
a) Sesuai aturan UU yang mengatur penempatan caleg perempuan sekurang-kurangnya 1 diantara 3 caleg guna memperbesar peluang perempuan terpilih. Hal ini berarti bahwa penentuan caleg terpilih berdasarkan nomor urutnya.

b) Melalui suara terbanyak. Hal ini sesungguhnya tidak sesuai dengan ketentuan UU Pemilu. Namun, ironisnya KPU sendiri tidak tegas dalam menentukan mekanisme pemilihan caleg, melainkan diserahkan kepada Partai Politik guna menentukan cara apa yang ingin dipilihnya. Saat ini diketahui 3 parpol besar yakni partai Golkar, Demokrat dan PAN telah memutuskan untuk menentukan caleg terpilihnya berdasarkan suara terbayak, sehingga, sekalipun seandainya parpol ini telah menempatkan $30 \%$ perempuan caleg sesuai dengan urutan nomor berdasarkan sistem zipper, tidak serta merta akan menjamin perempuan berpeluang lebih banyak untuk terpilih.

c) Berdasarkan pengalaman pada pemilu 2004 telah terjadi penurunan angka keterwakilan perempuan dari pemilu 1992 (12\%) menjadi 9\% pada Pemilu 1999. Adanya ketentuan kuota $30 \%$ bagi perempuan yang diterapkan pada Pemilu 2004 memang berhasil mendongkrak tingkat keterwakilan perempuan menjadi sebesar $11 \%$, namun harus diakui bahwa persentase ini masih di bawah perolehan pemilu tahun 1992 yang notabene belum menerapkan kuota $30 \%$ bagi perempuan. Walau agak sulit, perlu adanya pemikiran untuk mengusulkan kandidat-kandidat independen guna membuka peluang masuknya perempuan tanpa melalui jalur Parpol yang dirasakan masih kental dengan warna patriarki melalui jalur lain.

Perolehan wakil perempuan di lembaga legislatif secara nasional, baik di tingkat provinsi maupun kabupaten / kota adalah mengacu pada laporan United Nations Development Programme (UNDP) Indonesia Tahun 2010. Berdasarkan Undang-Undang Dasar Republik Indonesia tidak ada batasan terhadap partisipasi dan keterwakilan perempuan dalam politik. Meskipun

\section{\begin{tabular}{l|l} 
al-Daulah \\
Vol. G, No.1 April 2016
\end{tabular}}


keterlibatan perempuan dalam politik meningkat, namun keterwakilan mereka dalam lembaga legislatif, baik tingkat nasional, provinsi, serta kabupaten/kota masih rendah.

Berkaitan dengan keterwakilan perempuan dalam politik ini, maka gerakan perempuan di Indonesia memiliki keterlibatan aktif di bidang politik, tetapi masih ada kesenjangan dalam hal partisipasi dan keterwakilan perempuan di struktur politik formal. Mereka belum terwakili secara setara di lembaga legislatif tingkat nasional sejak tahun 1955, ketika perempuan menduduki 5,9 persen kursi di parlemen. Meskipun telah ada kecenderungan meningkat dalam hal keterwakilan perempuan sejak tahun 1971, ada beberapa pengecualian, termasuk pada Pemilu 1977 ketika jumlah perempuan terpilih melorot dari 7,8 persen menjadi 6,3 persen jika dibandingkan dengan Pemilu sebelumnya (1971) dan kembali mengalami penurunan lagi pada pemilu 1999 menjadi 9 persen jika dibandingkan dengan pemilu sebelumnya sebesar 10,8 persen pada tahun 1997. Meskipun demikian peningkatan keterwakilan perempuan di DPR RI pada dua pemilu terakhir, 11,8 persen pada tahun 2004, dan 18 persen pada pemilu 2009 cukup substantif. Kecenderungan meningkat dalam hal keterwakilan perempuan di DPD RI dari 22,6 persen pada 2004 menjadi 26,5 persen pada pemilu 2009 juga cukup menggembirakan ${ }^{19}$.

Pentingnya keterwakilan perempuan dalam politik, terutama di lembaga perwakilan rakyat sendiri, bukannya tanpa alasan yang mendasar, melihat bahwa pemenuhan keterwakilan perempuan pada pemilu 2004 tergolong rendah, hanya mencapai $11.3 \%$. Angka ini mengalami kenaikan 2\% jika dibandingkan dengan pencapaian pada pemilu 1999 sebesar 9\% di tingkat nasional, ${ }^{20}$ sementara besarnya keterwakilan perempuan dalam lembaga legislatif di Provinsi Jawa Timur pada tahun 1999 hanya 10 orang $(10 \%)$ dari 11 partai politik peserta pemilu 1999 dan 1 lembaga TNI/POLRI, yaitu; 4 orang dari PKB, 3 orang dari PDIP, 2

19 U N DP, Partisipasi Perempuan dalam Politik dan Pemerintahan, (Jakarta: U N DP, 2010), 3.

$20 \mathrm{lbid}$. 
orang dari Golkar, TNIPOLRI, PPP, 1 orang dari PAN, dan PBB, PNI-FM, PKU, PDR, PKP, PBI tidak mendapatkan kursi. Perolehan keterwakilan perempuan meningkat menjadi 14 atau $14 \%$. untuk pemilu tahun 2004 yang diikuti 9 partai politik peserta pemilu, yaitu; 4 orang PKB, 4 orang PDIP, 2 orang Golkar, 3 orang Demokrat, 1 orang PPP, PAN, PKS, PBB, serta PDS.

Pada pemilu tahun 2009, partai politik yang mengikuti sebanyak pemilu 12 partai, tidak semuanya mendapatkan kursi. Adapun partai politik peserta pemilu tersebut adalah : 7 orang dari Demokrat, 3 orang PDIP, 2 orang dari PKB, 1 orang dari Golkar, 2 orang dari Gerindra, 1 orang PPP, 2 orang dari partai Hanura, 1 orang dari Partai Bintang Reformasi. Untuk pemilu 2009, pemerintah mengeluarkan kebijakan terbaru tentang pemilu yang memperkuat keterlibatan perempuan dalam politik formal yaitu UU Pemilu Nomor 10/2008. Pada Pasal 8 ayat (1) butir (d) menyatakan bahwa partai politik dapat menjadi peserta Pemilu setelah memenuhi persyaratan menyertakan sekurang-kurangnya $30 \%$ keterwakilan perempuan pada kepengurusan partai politik tingkat pusat. Legalitas keterlibatan perempuan dalam Pemilu dengan kuota 30\% dianggap suatu kemenangan bagi para pengusung gender yang menyerukan Keadilan dan Kesetaraan Gender (KKG). Lebih jauh, Pasal 66 ayat 2 UU Nomor 10/2008 juga menyebutkan KPU, KPU provinsi, dan KPU kabupaten/kota mengumumkan persentase keterwakilan perempuan dalam daftar calon tetap parpol pada media cetak harian dan media elektronik nasional. Sementara di Pasal 2 ayat 3 UU Parpol disebutkan bahwa pendirian dan pembentukan parpol menyertakan 30\% keterwakilan perempuan. Lebih jauh, di Pasal 20 tentang kepengurusan parpol disebutkan juga tentang penyusunannya yang memperhatikan keterwakilan perempuan dalam kuota yang paling rendah.

Implementasi Undang-Undang pemilu No. 8 Tahun 2012 masih memunculkan problem di beberapa tingkatan; pertama, di tingkat substansi, UU ini belum menyebutkan secara tegas adanya 
sanksi bagi Parpol yang tidak memenuhi ketentuan 30\% kuota perempuan dalam daftar caleg, sanksi yang hanya berupa pemuatan Parpol yang gagal memenuhi kuota tersebut dalam media massa. Namun sanksi tersebut dikhawatirkan belum mampu membuat efek jera saat masyarakat pemilih tidak menganggap kegagalan tersebut menjadi sebuah masalah. Sisi lain sanksi ini tidak memberi efek pada menguatnya komitmen parpol dalam memenuhi kuota 30\% tersebut. Kedua, di tingkat partai masih banyak parpol yang kesulitan memenuhi kuota 30\% perempuan dalam daftar calon legislatif (Caleg), setidaknya ada 10 partai yang hanya mampu memenuhi kuota $27 \%$. Pihak lain Parpol pun melakukan pelanggaran dalam proses pembuatan daftar calon legislatif yang tidak sesuai dengan sistem zipper yang disyaratkan dalam UU Pemilu. Ketiga, di tingkat perempuan masih banyak ditemukan caleg perempuan yang tidak memenuhi syarat terkait dengan syarat administrasi, banyak perempuan tidak memiliki dukungan massa, kemampuan finansial serta rendahnya pengalaman politik. ${ }^{21}$

\section{Peluang dan Tantangan Politik Perempuan dalam Perspektif Budaya}

Berdasarkan data dari kaukus perempuan politik di Jawa Timur, tersirat beberapa persoalan menyangkut partisipasi politik perempuan; Pertama adanya keengganan Partai Politik tertentu untuk merekrut perempuan sesuai quota $30 \%$, sehingga ada di antara perempuan yang direkrut menjadi caleg oleh Parpol tertentu berada pada nomor sepatu; Kedua, ternyata banyak kaum perempuan yang belum siap masuk/terlibat dalam dunia politik dengan alasan pendidikan rendah dan belum memiliki pengetahuan yang memadai tentang dunia politik; Ketiga, ada kecenderungan kaum perempuan menganggap bahwa dunia

${ }^{21}$ Kebijakan parpol sangat menentukan keberhasilan keterwakilan perempuan dalam lembaga legislatif. 
politik adalah dunianya laki-laki, sehingga dianggap tabu bagi kaum perempuan.

Dalam perspektif budaya, terdapat nilai-nilai budaya yang berperan dalam membentuk realitas sosial yang menghambat proses kesetaraan jender dalam dunia politik, di antaranya:

a) Adanya realitas tingginya rasa ketergantungan perempuan terhadap laki-laki, karena kepribadian yang dibentuk oleh nilai-nilai budaya, sifat budaya patriakhi;

b) Stereotipe yang melekat pada laki-laki dan perempuan;

c) Pembagian kerja antara laki-laki dan perempuan yang mengakibatkan munculnya konsep ruang Domestik dan ruang Publik;

d) Adanya berbagai peraturan/adat yang bias jender (UU No. 5/1979 Pemerintahan Desa dan UU No.1/1974 tentang perkawinan, dan tradisi perkawinan adat;

e) Nilai-nilai agama yang menyatakan bahwa perempuan tidak boleh menjadi pemimpin dan beberapa ayat yang menekankan agar perempuan tunduk pada suaminya sebagaimana mereka taat dan tunduk pada Tuhan;

f) Kemiskinan, tingkat pendidikan dan kesehatan rendah, dan kondisi geografis. Ketiga kondisi ini sangat berpengaruh pada cara berpikir perempuan, jati diri dan kepribadian;

g) Globalisasi. Dampak ekonomi global terhadap perempuan: perempuan dianggap tidak memiliki skill sehingga banyak perempuan bekerja sebagai wanita penghibur, pembantu rumah tangga dan buruh pabrik/perusahaan;

h) Buta politik. Berbagai kegiatan yang banyak dilakukan organisasi perempuan dan pemerintah terhadap perempuan cenderung lebih menyuburkan posisi perempuan pada ruang domestik;

i) Mitologi. Sejarah pencipataan dalam tradisi lisan yang mengagungkan eksistensi laki-laki;

j) Menjamurnya promosi atau pusat kecantikan, kebugaran dan keperkasaan lelaki. 
Peluang perempuan terlibat dalam dunia politik dan refleksinya pada komunitas kaukus perempuan, sebenarnya telah terbuka lebar sebagaimana termuat dalam beberapa peraturan perundang-undangan dan beberapa fakta empiris, di antaranya; Undang-Undang No. 22 Tahun 1999 tentang Pemerintahan Daerah sebagaimana dirubah menjadi Undang-Undang Nomor 32 Tahun 2004; Undang-Undang No.8 Tahun 2012 tentang Pemilihan Umum; perimbangan jumlah penduduk perempuan lebih besar di banding laki-laki; sosialisasi dan pelestarian nilai-nilai tentang konsep wanita modern; adanya kemudahan akses untuk pendidikan(formal dan nonformal) dan kesehatan(KB); UndangUndang No. 9 Tahun 2000 tentang Pengarusutamaan Jender dalam Pembangunan; serta berbagai konvensi produksi internasional (Konvensi PBB tentang penghapusan semua bentuk diskriminasi terhadap perempuan (UU No.7/1984); Konvensi ILO No. 100 dan 111 tentang persamaan hak/perlakuan yang sama dan penghapusan diskriminasi upah dan jabatan (UU No. 80/1957 dan UU No. 21/1999); Konvensi PBB tentang hak-hak berpolitik bagi perempuan(UU No. 68/1968); Munculnya dan bangkitnya berbagai organisasi perempuan (LSM) yang memiliki perhatian khusus terhadap perempuan; Rencana Pembangunan Jangka Panjang yang menyinggung tentang kesetaraan dan keadilan serta pemberdayaan perempuan dan anak; serta adanya paradigma berpikir kaum lelaki sudah mulai berubah ke arah kemajuan.

\section{Analisis Hukum Islam terhadap Partisipasi Politik Perempuan}

Islam menempatkan perempuan dalam posisi yang tinggi. Beberapa pranata sosial Arab Jahiliyyah yang diskriminatif, bahkan cenderung tidak menghargai perempuan, berhasil diperbaiki. Semula, perempuan tidak berhak mendapat warisan, bahkan perempuan di zaman jahiliyyah dipandang sebagai barang yang dapat diwariskan. Tradisi itu hilang setelah Islam diturunkan dan perempuan mendapat kedudukan yang setara dengan lakilaki. 
Dalam bidang politik, banyak wanita muslimah yang ikut dalam kegiatan politik praktis. Dalam pertempuran, Ummu Aiman dan Aisyah tercatat sebagai anggota regu penolong korban yang terluka dan menyiapkan kebutuhan makan dan minum pasukan. Bahkan, Aisyah pernah memimpin pasukan dalam perang Jamal.

Pada masa selanjutnya, ketika pemerintahan Islam dipegang oleh daulah yang berdasarkan dinasti, terdapat beberapa perempuan yang diangkat sebagai kepala negara, seperti Syajarah al-Dur (Mesir), Padisyah Khatun (dinsati Mongol), dan Sulthanah Taj al-Alam Safiataddin Shah (Aceh)..22

Islam memberikan kesempatan kepada kaum perempuan yang berkecimpung dalam kegiatan politik, ini bisa terlihat pada banyak ayat dalam al-Qur'an yang memerintahkan amar ma'ruf nahi munkar. Ini berlaku untuk segala macam kegiatan, tidak terkecuali dalam bidang politik dan kenegaraan. Perempuan juga turut bertanggungjawab dalam hal ini. ${ }^{23}$

Berdasarkan hal tersebut, maka perempuan dalam Islam juga memiliki hak untuk berpolitik. Hak untuk berpolitik artinya hak untuk menjadi anggota lembaga perwakilan, dan untuk memperoleh kekuasaan, seperti memimpin lembaga formal, organisasi, partai, dan presiden. Hak-hak politik perempuan tentunya akan terkait dengan hak asasi manusia secara umum. Hak asasi ini dimiliki tanpa membedakan dasar bangsa, ras, agama, begitu pula jenis kelamin, karena dasar hak asasi ini adalah bahwa manusia memperoleh kesempatan untuk berekmbang sesuai dengan bakat dari cita-citanya. ${ }^{24}$

Peran politik perempuan dalam sebuah lembaga formal bagi masyarakat muslim masih menjadi tema yang kuat untuk diperdebatkan. Perbincangan mengenai hak-hak politik

22 Sri Suhandjati Sukri, "Perempuan sebagai Kepala N egara" dalam Sri Suhandjati Sukri ed.al., Pemahaman Islam dan Tantangan Keadilan Jender, (Yogyakarta: Gama Media, 2002), 115.

${ }^{23}$ Huzaemah T. Yanggo, Fiqh Perempuan Kontemporer, (Jakarta: Al-Mawardi Prima, 2001), 152.

${ }^{24}$ Zaitunah Subhan, Perempuan dan Politik dalam Islam, (Yogyakarta: Pustaka Pesantren, 2006), 39. 
perempuan dalam wacana Islam menimbulkan dua aliran besar, yaitu aliran yang mengatakan bahwa Islam tidak mengakui hakhak politik perempuan dan aliran yang mengakui hak politik perempuan sebagaimana juga diberikan kepada pria. ${ }^{25}$

Di antara alasan yang dikemukakan pendapat pertama yang menolak adanya partisipasi politik perempuan adalah bahwa tugas-tugas politik sangat berat dan perempuan tidak akan mampu menanggungnya karena akal dan tenaganya yang dianggap lemah. Untuk jabatan yudikatif, mayoritas ulama memberikan fatwa terlarang dipegang perempuan dan sebagian lagi memberikan batasan-batasan. ${ }^{26}$

Pandangan pertama tersebut didominasi oleh pandangan ulama klasik. Pandangan ulama klasik di atas kini berhadapan dengan ruas-ruas modernitas yang terbuka lebar. Keterbukaan ruang bagi perempuan untuk mengikuti pendidikan sampai setinggi-tingginya telah melahirkan kemampuan-kemampuan mereka dalam segala urusan yang sebelumnya diklaim hanya menjadi milik laki-laki. Persepsi tendisius bahwa kaum perempuan kurang rasional, lebih emosional dan kurang kompeten menangani urusan domestik dan publik dibanding kaum laki-laki telah gugur dan tidak lagi polpuler. ${ }^{27}$ Berdasarkan hal tersebut, saat ini di kalangan mayoritas ulama muslim cenderung pada pendapat kedua, yang membolehkan wanita berpartisipasi dalam politik.

Selama ini, persepsi yang membatasi hak-hak politik perempuan tidak lepas dari pengaruh sistem nilai dan norma, steretype politik, serta wacana yang dikembangkan oleh penguasa. Oleh karenanya, pemerintah yang berwenang dalam memberdayakan perempuan harus berupaya menghilangkan stigma atas pembelengguan mereka. Dan relasi kuasa ini semaksimal mungkin tidak ditopang dengan penjelasan agama

25 lbid., 43.

${ }^{26}$ Husen Muhammad, Islam Agama Ramah Perempuan, 169.

27 Ibid., 170. 
yang bias jender, terlebih bila agama dijadikan alat legitimasi dalam pengambilan kebijakan negara. ${ }^{28}$

Bagi Indonesia, yang mayoritas penduduknya beragama Islam, status yang setara bagi perempuan dan peluang mereka dalam aktifitas politik, sesungguhnya telah mendapat dasar yuirids dalam UUD 1945. Keputusan politik yang menyediakan $30 \%$ kursi parlemen bagi mereka, merupakan salah satu peluang yang harus dimanfaatkan dengan sebaik-baiknya. Dalam hal ini, agama memang mengabsahkan ruang politik yang luas bagi perempuan.

Kehadiran perempuan secara lebih masif falam panggung politik struktural diharapkan akan mampu merumuskan kebijakan-kebijakan segara yang memberdayakan berjuta-juta kaum sejenisnya, menghapus kultur diskriminatif dan menghentikan kekerasan terhadap mereka yang masih terus berlangsung secara eskalatif, baik di ruang keluarga maupun publik. ${ }^{29}$

\section{Penutup}

Partisipasi politik perempuan adalah kegiatan sukarela kaum prempuan yang tergabung pada komunitas kaukus perempuan politik. Kaukus ini terdiri dari berbagai unsur, antara lain pemerhati politik, aktivis perempuan, dosen, perempuan parlemen, kader perempuan partai politik dan lain sebagainya, sehingga dalam kaukus ini mereka mengambil bagian pada proses pemilihan penguasa, baik secara langsung atau tidak langsung dalam proses pembentukan kebijakan umum.

Peluang perempuan untuk berpolitik terbuka lebar, namun terdapat beberapa hambatan yang dihadapi perempuan dalam berpolitik, di antaranya: dispemahaman gender dan subordinasi perempuan dalam politik, budaya politik patriarki, hambatan yang

28 Ibid., 49.

${ }^{29}$ Husen Muhammada, Islam Agama Ramah Perempuan, 172. 
bersifat individual, dan hambatan yang bersifat kelembagaan dan struktural.

Agar peluang politik perempuan bisa melewati hambatan tersebut, Kaukus Perempuan Politik Jawa Timur menganjurkan beberapa hal, yaitu: 1. Perempuan harus bersama-sama berjaringan, baik di dalam dan di luar partai partai politik. 2 . Perempuan melakukan lobi-lobi intensif untuk mendesak partai politik mengeluarkan aturan yang jelas dalam proses seleksi calon. 3. Menggunakan media massa secara efektif untuk mengkampanyekan isu-isu, dan kebutuhan perempuan untuk menyeimbangkan partisipasi dan representasi perempuan dan laki-laki. 4. Perlunya menggalang dukungan, komitmen dan kepercayaan kaum laki-laki dan semua pihak bagi para perempuan yang akan mencalonkan diri menjadi anggota partai politik atau anggota legislatif atau eksekutif; serta 5. Perlu adanya metode pelatihan politik bagi kandidat perempuan.

Islam memberikan kesempatan kepada kaum perempuan yang berkecimpung dalam kegiatan politik, ini bisa terlihat pada banyak ayat dalam al-Qur'an yang memerintahkan amar ma'ruf nahi munkar. Ini berlaku untuk segala macam kegiatan, tidak terkecuali dalam bidang politik dan kenegaraan. Perempuan juga turut bertanggungjawab dalam hal ini.

Berdasarkan hal tersebut, maka perempuan dalam Islam juga memiliki hak untuk berpolitik. Hak untuk berpolitik artinya hak untuk menjadi anggota lembaga perwakilan, dan untuk memperoleh kekuasaan, seperti memimpin lembaga formal, organisasi, partai, dan presiden. Hak-hak politik perempuan tentunya akan terkait dengan hak asasi manusia secara umum. Hak asasi ini dimiliki tanpa membedakan dasar bangsa, ras, agama, begitu pula jenis kelamin, karena dasar hak asasi ini adalah bahwa manusia memperoleh kesempatan untuk berkembang sesuai dengan bakat dari cita-citanya. 


\section{Daftar Pustaka}

Deputi Peningkatan Kualitas Hidup Perempuan. Panduan Rencana Aksi Peningkatan Partisipasi Politik Perempuan. Jakarta: Deputi Peningkatan Kualitas Hidup Perempuan, Kementerian

Negara Pemberdayaan Perempuan Republik Indonesia, 2006.

Fakih, Mansour. Analisis Gender dan Transformasi Sosial. Yogyakarta: Pustaka Pelajar, 2001.

Ja'far, Muhammad Anis. Qasim Perempuan dan Kekuasaan: Menelusuri Hak Politik dan Persoalan Gender dalam Islam. Jakarta: Zaman, 1998.

Kymlicka, Will. Contemporary Political Philosophy: An Introduction. Oxford: Clarendon Press, 1990.

Muhaimin. Menuju Kemandirian Politik Perempuan (Upaya Mengakhiri Depolitisasi Perempuan Di Indonesia). Yogyakarta: Kibar Press, 2008.

Surbakti, Ramlan. Memahami Ilmu Politik. Jakarta: PT. Gramedia Widiasarana Indonesia, 2009.

Triwanto, Herry. Profil Perempuan Anggota DPRD Provinsi Jawa Tengah Ditinjau Dari Perspektif Politik Gender. TesisSemarang: PPS Universitas diponegoro, 2009.

Undang-Undang Dasar Negara Kesatuan Republik Indonesia Tahun 1945.

Undang-Undang Republik Indonesia No. 20 Tahun 2003 tentang Sistem Pendidikan Nasional. Jakarta: Departemen Pendidikan Nasional Republik Indonesia, 2003.

UNDP. Partisipasi Perempuan Dalam Politik dan Pemerintahan. Jakarta: UNDP, 2010.

Wicaksono, MB. (ed). Modul Perempuan untuk Politik: Sebuah Panduan tentang Partisipasi Perempuan dalam Politik. Jakarta: Yayasan Jurnal Perempuan, 2004. 